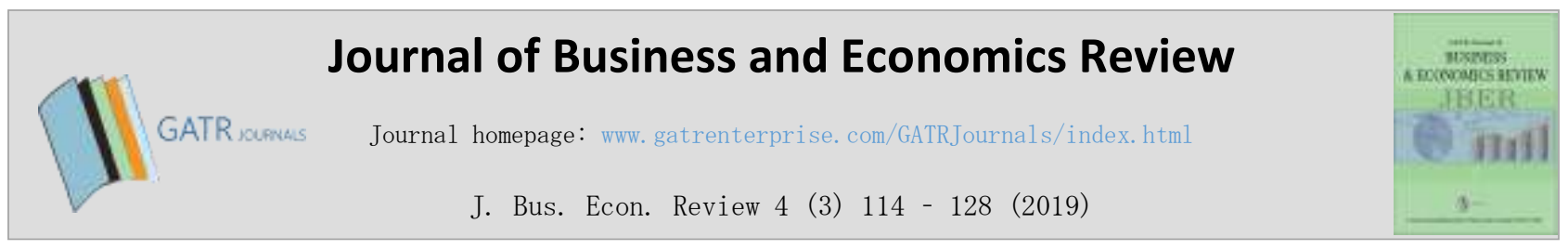

\title{
Manufacturing Sector and Economic Growth: A Panel Study of Selected African Countries
}

\author{
Clement Moyo ${ }^{1}$, Leward Jeke ${ }^{2}$ \\ ${ }^{12}$ Nelson Mandela University, South Africa
}

\begin{abstract}
Objective - The manufacturing sector plays an important role in any economy. However, Africa has experienced significant deindustrialisation over the last few decades, whilst economic growth has been on an upward trend over the same period. The high growth rates have mostly been propelled by improved macroeconomic stability and the commodity price boom. Further, the slowdown in commodity prices has recently caused a deceleration of economic growth which begs the question: Does promoting the manufacturing sector result in higher and sustainable economic growth and reduce unemployment? This study assesses the impact of the manufacturing sector on economic growth in 37 African countries.

Methodology/Technique - This study employs the System-GMM Model for the period between 1990 and 2017 . This technique is ideal as the number of cross-sectional units is greater than the number of time periods. This technique also caters for problems of endogeneity and heteroscedasticity.

Findings - The results show that manufacturing value has a positive effect on economic growth in African countries. Therefore, it is recommended that policy makers enact measures to boost manufacturing output.

Novelty -The deceleration of economic growth in African countries coupled with high unemployment and poverty levels has brought the issue of re-industrialisation into the spotlight. This study is vital for policy makers in African countries who seek to promote economic growth and employment levels. The study contributes to literature in African countries by incorporating variables such as human capital and institutional quality which are major determinants of economic growth.
\end{abstract}

Type of Paper: Empirical.

Keywords: Manufacturing Value Added; Economic Growth; African Countries; System-GMM.

Reference to this paper should be made as follows: Moyo, C; Jeke, L. (2019). Manufacturing Sector and Economic Growth: A Panel Study of Selected African Countries, J. Bus. Econ. Review, 4(3) $114-128$ https://doi.org/10.35609/jber.2019.4.3(1)

JEL Classification: C23, E23, O14, O40.

\footnotetext{
* Paper Info: Revised: June 18, 2019

Accepted: September 22, 2019

* Corresponding author: Clement Moyo

E-mail: clementmoyoz@yahoo.com

Affiliation: Nelson Mandela University, South Africa
} 


\section{Introduction}

The slowdown and volatility of primary commodity prices has presented a challenge to many African countries. Economic growth has decelerated slightly in the region over the last few years in response to the conclusion of the upward trend in commodity prices (African Development Bank, 2018). Export revenues as well as investments have subsequently declined. It is thought that the manufacturing sector poses a potential solution to reinvigorate the economy. The reliance on primary commodities should be reduced and more attention should be paid to the manufacturing sector which has a potential to revitalise industries thus ensuring better opportunities for growth and development. According to the African Development Bank (2018), African countries should strengthen their resilience to economic shock and diversify their economies in order to move to a new growth path propelled by productivity and innovation. The manufacturing sector has the potential to be a source of innovation by employing highly skilled labourers who have the ability to develop new technologies thus enhancing productivity. This is crucial as the world enters the Fourth Industrial Revolution (World Economic Forum, 2016).

According to the Kaldorian theory, the manufacturing sector is crucial for economic growth, however, data shows that for most African countries there has been a downward spiral in manufacturing to GDP ratio. The development of the manufacturing sector has been marked as one of the key policy tools for the structural transformation of any economy and is considered the best option for achieving full employment and economic growth (Kaldor, 1960; Rasiah, 1996). Kaldor's hypothesis is represented by three laws. Firstly, manufacturing is a major driver of economic growth. Secondly, manufacturing productivity growth has a positive impact on the manufacturing sector's output (Verdoorn's law) and lastly, output growth in the manufacturing sector is linked to productivity growth in other sectors of an economy.

A flourishing manufacturing sector is an important driver for sustainable job creation and economic growth in any country because of its links with other sectors. Furthermore, given its labour-intensive nature, the manufacturing sector may be more effective as a source of employment creation compared to other sectors in any given economy. The high growth rates in African countries over the last few decades have not brought about the expected level of decline in unemployment and poverty. According to the African Development Bank (2018), over the last few years, employment growth rates in most countries have been significantly lower than economic growth rates. Therefore, industrialisation has the potential to reduce high unemployment in African countries which is the major cause of high poverty rates and a lack of economic development.

This study examines the manufacturing and economic growth nexus in selected African countries for the period between 1990 and 2017. Specifically, this study provides an empirical analysis of the first Kaldorian law. The System-GMM model is selected due to the possibility of endogeneity and heteroscedasticity in the data. Furthermore, the model is suitable for the analysis since the number of cross-sectional units (37 countries) is greater than the time periods (28 years). There is scant empirical evidence on the effect of manufacturing on economic growth in African countries. Recent studies by Ududechinyere, Micheal and Mbam (2018), Tsoku, Mosikari, Xaba and Modise (2017) and Keho (2018) utilise time series techniques which may suffer from problems of multicollinearity, serial correlation and endogeneity. A recent panel study by Olamande and Oni (2016) suffers from the omitted variable bias as the model estimated excluded control variables and thus may overstate the impact of manufacturing on economic growth. This study incorporates variables that capture the macroeconomic environment, the foreign sector and the government sector. Furthermore, institutional quality and human capital, which are regarded as major determinants of economic growth, are included.

The study is structured as follows. Section two provides an overview of manufacturing and economic growth in African countries. Section three provides a brief survey of existing literature, while section four 
describes the methodology of the study. Section five presents the empirical results of the study and lastly, section six concludes the study and provides policy recommendations.

\section{Overview of Manufacturing and Economic Growth in African Countries}

Table 1 and 2 outline trends in manufacturing value added (MVA) as a percentage of GDP across different regions. Deindustrialisation is evident in all regions mostly due to the growth in consumption of services outpacing that of manufactured goods (Rodrik, 2016). SSA has recorded a quicker rate of deindustrialisation with MVA constantly below that of other regions as well as the world average during the period under consideration. According to Haraguchi, Cheng and Smeets (2017), deindustrialisation in developed countries with higher income levels is expected due to structural changes in their economies. The reduction of MVA in developing countries reflects change in concentration of manufacturing activities to a small number of countries, particularly those in Asia.

Table 1. Trends in Manufacturing Value Added

\begin{tabular}{|l|l|l|l|l|l|l|l|}
\hline $\begin{array}{c}\text { Region } \\
\text { Year }\end{array}$ & SSA & WORLD & LAC & SE & MENA & ECA & NA \\
\hline $1990-1995$ & 15.34 & & 19.17 & 16.58 & 11.75 & 18.37 & \\
\hline $1996-2000$ & 13.47 & 17.22 & 16.00 & 16.30 & 13.41 & 17.13 & 15.51 \\
\hline $2001-2005$ & 12.07 & 16.53 & 15.90 & 16.04 & 14.92 & 15.65 & 13.25 \\
\hline $2006-2010$ & 10.17 & 16.40 & 14.81 & 16.47 & 13.50 & 14.39 & 12.26 \\
\hline $2011-2017$ & 9.92 & 15.69 & 13.27 & 15.21 & 13.67 & 13.93 & 11.84 \\
\hline
\end{tabular}

Source: World Bank (2019), Note: SSA - Sub-Saharan Africa, LAC - Latin America and Caribbean countries, SE -

South Asia, MENA - Middle East and North African, ECA - Europe and Central Asia and NA - North America.

Table 2. Trends in Economic Growth

\begin{tabular}{|l|l|l|l|l|l|l|l|}
\hline $\begin{array}{l}\text { Rear } \\
\text { Region }\end{array}$ & SSA & WORLD & LAC & SE & MENA & ECA & NA \\
\hline $1990-1995$ & 1.00 & 2.28 & 2.69 & 5.08 & 5.09 & 0.76 & 2.38 \\
\hline $1996-2000$ & 3.36 & 3.45 & 2.94 & 5.61 & 4.08 & 2.89 & 4.27 \\
\hline $2001-2005$ & 5.53 & 3.05 & 2.66 & 6.31 & 4.29 & 2.37 & 2.54 \\
\hline $2006-2010$ & 5.36 & 2.58 & 3.74 & 7.65 & 4.23 & 1.35 & 0.82 \\
\hline $2011-2017$ & 3.64 & 2.81 & 1.71 & 6.55 & 3.15 & 1.69 & 2.11 \\
\hline
\end{tabular}

Source: World Bank (2019)

Trends in GDP growth show that SSA has recorded high economic growth since the mid-1990s propelled by the commodity price boom, an increase in domestic demand, an improvement in macroeconomic stability and financial reforms conducted in the late 80s and early 90s (Morris \& Fessehaie, 2014). The growth rate peaked at $5.53 \%$ between 2001 and 2005 but has reduced in recent years partly due to the slowdown in the growth of commodity prices and the sluggish recovery from the 2008/09 global financial crisis. Compared to other regions, the SSA growth average sits just behind that of MENA and South Asian countries and above the world average. South Asian countries have been able to sustain high levels of economic growth mostly due to exports of manufactured products which have increased in value over the years (Bhorat et. al., 2017). 


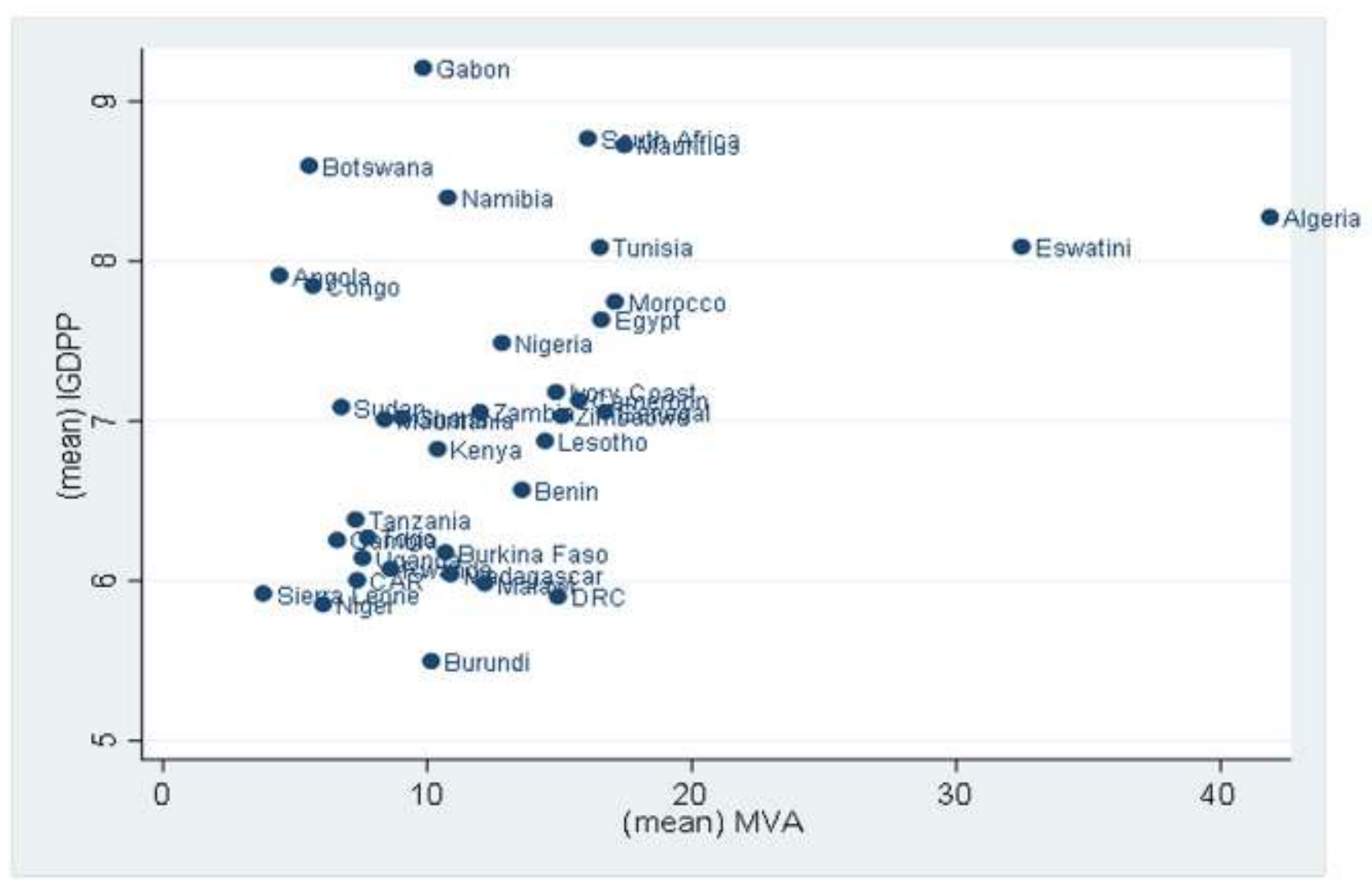

Figure 1. Scatter plot of MVA and GDP per capita in selected African countries

Figure 1 shows a scatter plot of the relationship between the natural logarithm of GDP per capita and MVA. There is evidence of a positive relationship between the variables with Algeria and Eswatini recording the highest MVA figures and are ranking in the top 10 countries with the highest incomes. Mauritius and South Africa also recorded high income and moderately high MVA levels compared to other countries. On the other hand, countries such as Botswana, Gabon and Namibia have high per capita incomes but low levels of MVA. Botswana has been one of the success stories in the world in terms income propelled by diamond production and trade. Gabon's high per capita income has been as a result of petroleum production and foreign direct investments while Namibia's rise in incomes is due to the growth of the services sector. The figure also shows several low-income and low MVA countries, suggesting that there is a link between the variables.

\section{Literature Review}

This section provides a brief discussion of relevant literature relating to the effect of manufacturing on economic growth. Both theoretical and empirical literature are discussed.

\subsection{Theoretical Literature}

Kaldor's first law of growth states that manufacturing is the engine of growth. This suggests that the faster the growth rate in manufacturing output is, the faster the growth rate of the economy as a whole will be (Rocha, 2018). The Kaldorian theory concentrates on the demand-supply relationships in the manufacturing 
sector and explores the importance of industrialisation of the manufacturing sector. According to Kaldor (1960), the manufacturing sector may absorb goods from other sectors such as agriculture and mining which boosts output in the whole economy. Furthermore, the growth on manufacturing enhances demand for services such banking and insurance thus promoting the tertiary sector (Cantore, Clara, Lavopa \& Soare (2017).

Structuralists provide support for Kaldor (1960) in suggesting that the expansion of the manufacturing sector is crucial for any given economy (Rasiah, 1996). The structuralism theory asserts that the manufacturing sector produces capital goods that are used in diverse industrial divisions and subdivisions and is a powerful instrument for diffusing practical change within the economy. Rasiah (1996) states that the manufacturing sector must be given special attention as it plays a dynamic role in expanding its own growth and that of the other sectors. Rocha (2018) emphasizes that the structuralism view usually stresses that economic development is strongly linked to a radical transformation in the structure of production to suppress obstacles, bottlenecks and other rigidities of underdevelopment. The structuralism literature, therefore, highlights the importance of industrialisation as a process of structural change where the manufacturing sector plays a central role (Chenery, 1975).

According to Rocha (2018), the structuralism strand states that without dynamic industrialisation, it is not feasible to increase employment, productivity and income per capita and, consequently, to reduce poverty. The main argument stresses that development involves a production reallocation from low productivity to high productivity sectors where increasing returns to scale prevail.

\subsection{Empirical Literature}

The Kaldorian hypothesis emphasising the effect of manufacturing sector output on economic growth has been subject to a great deal of interest in existing literature. Both time-series and panel data studies have analysed the link between the variables, and these lend support to Kaldor's hypothesis.

Jeon (2006) found support for Kaldor's approach to economic growth and development in China using time series and panel data analysis. Chakravarty and Mitra (2009) employed a VAR model and concluded that manufacturing is a driver of economic growth in India. The authors further assert that the manufacturing sector also boosts sectors in the medium to long-term. Using the Johansen test, Singariya and Sinha (2015) found that there is a long-term relationship between the variables in India and the direction of causality from manufacturing to GDP. However, the authors conclude that agriculture plays a more vital role in promoting GDP. Tsoku et. al. (2017) also provide support for Kaldor's hypothesis in South Africa and similarly, there is unidirectional causality from manufacturing to economic growth. Ududechinyere et. al. (2018) concludes that manufacturing output is crucial for economic growth in Nigeria. However, they found that causality runs from GDP to the manufacturing sector.

A number of panel data studies are evident in literature. Libanio and Moro (2006) found evidence supporting Kaldor's hypothesis in Latin American countries. Furthermore, the results indicated the presence of increasing returns to scale in the larger countries in Latin America. Szirmai and Verspagen (2010) found that manufacturing is an engine for growth, particularly in poorer countries. Moreover, manufacturing seems to play a much more pronounced role in promoting economic growth in Latin American countries while in African countries, manufacturing does not significantly impact on economic growth. By analysing existing literature, Szirmai (2012) corroborates the results of Szirmai and Verspagen (2010) by arguing that manufacturing has been vital for economic growth for developing countries over the years, however, the services sector has contributed more recently to this, particularly in developed countries.

Mercan, Kizilkaya and Okde (2015) found that manufacturing output enhances economic growth in Newly Industrialised Countries. Su and Yao (2016) conclude that manufacturing growth enhances incentives for savings and technological accumulation which are crucial for economic growth in middle income

J. Bus. Econ. Review 4 (3) 114 - 128 (2019) 
countries. Marconi, Reis and Araùjo (2016) corroborate the results of Su and Yao (2016) in concluding that manufacturing output growth is essential for economic growth and productivity, particularly in middleincome countries. Olamade and Oni (2016) provided evidence supporting the hypothesis that manufacturing is an engine for growth in 28 African countries and argues that de-industrialisation may have an adverse effect on economic growth. Cantore et. al. (2017) decomposes the effect of the manufacturing sector on economic growth into structural transformation and employment effects in 80 countries and concludes that manufacturing enhances growth through structural change involving an increase in productivity. Keho (2018) concludes that manufacturing output enhances economic growth in most ECOWAS countries. Furthermore, the effect is more pronounced in Nigeria and Senegal where manufacturing output promotes output growth in agriculture and the services sectors.

The theoretical literature emphasises the role that the manufacturing sector plays in promoting economic growth. The manufacturing sector boosts output in both the primary and tertiary sectors in an economy. Furthermore, employment creation and poverty reduction may be enhanced which in turn increases demand for goods and services thus further increasing economic growth. The empirical literature corroborates the theoretical literature to a large extent. However, there a number of studies which reveal that the relationship between manufacturing output and economic growth is ambiguous. There is ambiguity in the direction of causality as shown by the findings of Ududechinyere et. al. (2018). Furthermore, findings by Szirmai (2012) and Singariya and Sinha (2015) show that the manufacturing sector may not be the most important sector influencing economic growth. It is against this backdrop that this study tests the validity of Kaldor's hypothesis in African countries in order to determine the importance of the manufacturing sector in a period where African countries have undergone premature de-industrialisation.

\section{Data and Methodology}

This section discusses the methodological approach used in this study and describes the data used in the empirical analysis.

\subsection{Methodology}

This study utilises a panel data approach for the empirical analysis due to its ability to control heterogeneity present in countries, to permit more degrees of freedom and to minimise the possibility of multicollinearity compared to time series or cross-sectional techniques (Hsiao, 2003, Baltagi, 2005, Brooks, 2008). A panel data model can be specified as follows:

$y_{i t}=\alpha+x_{i t}^{\prime} \beta+u_{i t} \quad i=1, \ldots, N ; t=1, \ldots, T$

where i represents countries while $t$ represents time. The two subscripts $i$ and $t$ denote the cross-sectional and the time-series components respectively: $\alpha$ is a scalar, $\beta$ is a slope coefficient and $x_{i t}^{\prime}$ denotes the independent or explanatory variables in the model (Baltagi, 2005). The one-way error component model for the error term is specified as follows:

$u_{i t}=\mu_{i}+v_{i t}$

where $\mu_{\mathrm{i}}$ represents the unobservable, individual-specific and time-invariant disturbance, which caters for any individual-specific effect omitted from the regression model while $v_{i t}$ is the remainder disturbance that is variant with respect to time, individuals, firms or countries (Baltagi, 2005). Both $\mu_{\mathrm{i}}$ and $\mathrm{v}_{\mathrm{it}}$ are identically and independently distributed. 
The conventional panel data estimation techniques include the pooled OLS, fixed effects (FE), random effects (RE), and instrumental variables models like Generalised Methods of Moments (GMM). A major shortcoming of the pooled OLS model is that it ignores the heterogeneity existing in different cross-sectional units (Hill, Griffiths \& Lim, 2012). A limitation of the fixed-effect within-group estimator is that it may eliminate long-term effects and hence distort parameter estimates (Gujarati \& Porter, 2009). The models mentioned above may also suffer from endogeneity introduced by the omitted variable bias or measurement errors due to inaccurate proxies (Baltagi, 2005). Due to the unavailability of data for some African countries, the researchers omit certain variables. Furthermore, property rights are used as a measure of institutional quality which may not be the most accurate proxy. As such, the study utilises the GMM estimator.

Arellano and Bond, (1991), Arellano and Bover, (1995) and Blundell and Bond (1998) propose various GMM estimation techniques which can be used in the presence of heteroscedasticity by making use of the orthogonality conditions which cater for endogeneity (Baum \& Schaffer, 2003). The GMM estimators are designed for panels with a small number of time periods $\mathrm{T}$ and a large number of cross-sectional units (Roodman, 2009).

A formal representation of the methods of moments begins with the specification of a linear regression model:

$y_{t}=x_{t}^{\prime} \beta_{0}+\varepsilon_{t} \quad t=1,2, \ldots, T$

where $x_{t}^{\prime}$ is a $K \times 1$ vector of explanatory variables, $\varepsilon_{t}$ is the error term and $\beta_{0}$ is a vector of coefficients (Greene, 2002). The conditional expectations of $y_{t}$ is $E\left(y_{t} \backslash x_{t}=x_{t}^{\prime} \beta_{0}\right.$ meaning that $E\left(\varepsilon_{t} \backslash x_{t}\right)=0$. The unconditional population moment condition is specified as follows:

$g\left(\beta_{0}\right)=E\left[x_{t} \varepsilon_{t}\right]=E\left[x_{t}\left(y_{t}-x_{t}^{\prime} \beta_{0}\right)\right]=0$

The sample moment condition is as follows:

$$
\begin{gathered}
g_{T}(\hat{\beta})=\frac{1}{T} \sum_{t=1}^{T} x_{t}\left(y_{t}-x_{t}^{\prime} \hat{\beta}\right)=\frac{1}{T} \sum_{t=1}^{T} x_{t} x_{t}^{\prime} \hat{\beta} \\
=0
\end{gathered}
$$

The method of moments estimator is found by solving the above sample moment condition which results in the following expression:

$$
\hat{\beta}_{M M}=\left(\sum_{t=1}^{T} x_{t} x_{t}^{\prime}\right)^{-1} \sum_{t=1}^{T} x_{t} y_{t}
$$

If some of the explanatory variables are correlated with the error term (endogenous) the linear regression model would be specified as follows:

$y_{t}=x_{1 t}^{\prime} \Upsilon_{0}+x_{2 t}^{\prime} \delta_{0}+\varepsilon_{t}$

Where $\mathrm{x}_{1 \mathrm{t}}^{\prime}$ are the exogenous regressors, $\mathrm{x}_{2 \mathrm{t}}^{\prime}$ are the endogenous regressors while $\Upsilon_{0}$ and $\delta_{0}$ are the coefficients. In order to estimate the above equation, instruments are required. These are variables that are 
correlated with the endogenous regressors but uncorrelated with the error term. The unconditional moment condition is specified as follows:

$g\left(\beta_{0}\right)=E\left[z_{t} \varepsilon_{t}\right]=E\left[z_{t}\left(y_{t}-x_{t}^{\prime} \beta_{0}\right)\right]=0$

Where $z_{t}$ are the instruments.

The sample moment condition is given by:

$g_{T}(\hat{\beta})=\frac{1}{T} \sum_{t=1}^{T} z_{t}\left(y_{t}-x_{t}^{\prime} \hat{\beta}\right)=0$

Therefore, the method of moments estimator is this case is as follows:

$\hat{\beta}_{M M(I V)}=\left(\sum_{t=1}^{T} z_{t} x_{t}^{\prime}\right)^{-1} \sum_{t=1}^{T} z_{t} y_{t}$

If the number of instruments is greater than the number of parameters to be estimated then the equation is overidentified (Greene, 2002). The ideal estimator is the GMM technique which solves the equation by minimising the vector of empirical moments, $\frac{1}{T} \sum_{t=1}^{T} z_{t}\left(y_{t}-x_{t}^{\prime} \beta\right)$. The GMM estimator minimises the weighted quadratic function of moments specified as follows:

$J(\hat{\beta})=\left[\frac{1}{T} \sum_{t=1}^{T} z_{t}\left(y_{t}-x_{t}^{\prime} \beta\right)\right]^{\prime} W\left[\frac{1}{T} \sum_{t=1}^{T} z_{t}\left(y_{t}-x_{t}^{\prime} \beta\right]\right.$

where $\mathrm{W}$ is the weighting matrix

The empirical model of the study is specified as follows:

$$
\begin{gathered}
G D P=\alpha_{1}+\alpha_{2} M V A+\alpha_{3} I N F+\alpha_{4} T R A D E+\alpha_{5} G O V+\alpha_{6} I N V+\alpha_{7} H U M A N+\alpha_{8} C R E D+\alpha_{9} I N S T \\
+\varepsilon
\end{gathered}
$$

Where $\varepsilon$ is the disturbance term. The rest of the variables are described in Table 1 above.

\subsection{Data Analysis}

Table 3. Description of Variables

\begin{tabular}{|l|l|l|l|}
\hline Variable & Description & a priori expectations & Source \\
\hline GDP & GDP per capita & & World Bank \\
\hline MVA & Manufacturing value added & Positive & World Bank \\
\hline INV & Gross fixed capital formation & Positive & World Bank \\
\hline TRADE & Imports plus exports & Positive & World Bank \\
\hline
\end{tabular}




\begin{tabular}{|l|l|l|l|}
\hline GOV & Government consumption & Positive & World Bank \\
\hline INF & Inflation & Negative & World Bank \\
\hline HUMAN & Human capital index & Positive & Penn World Tables \\
\hline CRED & Domestic credit to the private sector & Positive & World Bank \\
\hline INST & Institutional quality & Positive & Heritage Foundation \\
\hline
\end{tabular}

Table 3 provides a description of the data, their sources as well as a priori expectations (GDP per capita is the dependent variable). The period selected is 1990-2017 which covers the period where deindustrialisation seemed to occur in most African countries. The number of countries chosen for the analysis is 37 (see appendix for the country list). Table 4 presents the descriptive statistics. The average MVA for the period 1990-2017 for the selected African countries is 12.15\%, which is lower than that of other developing/emerging country regions such as South Asia and Latin America and Caribbean countries which average $16.07 \%$ and $15.64 \%$ respectively. Algeria and Eswatini have the highest MVA in Africa. GDP per capita averages $\$ 1983.05$ does not provide a great indication of the levels of income in African countries where inequality is rife. Most countries have low levels of income which has slowed down the progress in reducing inequality and poverty levels. The high standard deviation is an indication of the variability in incomes with countries such as Mauritius, South Africa, Algeria, Botswana, Eswatini, Tunisia, Gabon and Namibia recording high levels of income.

The mean for inflation is $56.42 \%$ which attests to the history of high inflation rates that have been witnessed in African countries. However, several countries have managed to reduce inflation rates to single digit figure over the last decade. Investment as a percentage of GDP averages $20.48 \%$ which is lower than the fast-growing emerging economies in Asia (Moyo \& Le Roux, 2018). Investments in infrastructure are crucial for economic growth, however, the region continues to lag behind in this regard. Measures should be put in place to encourage investments such as promoting savings, reducing interest rates, ensuring macroeconomic stability and developing the financial sector.

Table 4. Descriptive Statistics

\begin{tabular}{|l|l|l|l|l|l|}
\hline Variable & Mean & Max & Min & Std. Dev & No. of obs \\
\hline GDP & 1983.05 & 11925.78 & 204.72 & 2230.61 & 1036 \\
\hline MVA & 12.15 & 50.64 & 1.53 & 7.48 & 966 \\
\hline INF & 56.42 & 23773.13 & -11.69 & 799.74 & 965 \\
\hline INV & 20.48 & 60.02 & -2.42 & 8.34 & 977 \\
\hline TRADE & 67.54 & 170.41 & 11.09 & 29.90 & 999 \\
\hline GOV & 15.11 & 40.44 & 2.05 & 5.27 & 947 \\
\hline CRED & 21.94 & 160.12 & 0.49 & 25.35 & 994 \\
\hline HUMAN & 1.71 & 2.80 & 1.03 & 1.71 & 925 \\
\hline INST & 38.44 & 75 & 5 & 15.19 & 785 \\
\hline
\end{tabular}

Trade as a percentage of GDP averages $67.54 \%$ which indicates that African countries are open to trade to a certain extent. The most open countries are the smaller countries such as Botswana, Congo, Eswatini, Lesotho, Mauritania, Mauritius, Namibia as well as Tunisia. Government consumption expenditure as a percentage of GDP averages $15.11 \%$. Government expenditure directed at investment activities boosts economic growth compared to consumption purposes. However, government expenditure may also hinder economic growth if it crowds out investments (Romer, 2012).

Table 5. Correlation Analysis 


\begin{tabular}{|l|l|l|l|l|l|l|l|l|l|}
\hline & LGDPP & MVA & INF & INV & TRADE & GOV & CRED & HUMAN & INST \\
\hline LGDPP & 1 & & & & & & & & \\
\hline MVA & $0.32^{*}$ & 1 & & & & & & & \\
\hline INF & -0.04 & -0.06 & 1 & & & & & & \\
\hline INV & $0.39^{*}$ & $0.08^{*}$ & -0.06 & 1 & & & & & \\
\hline TRADE & $0.51^{*}$ & $0.16^{*}$ & -0.03 & $0.34^{*}$ & 1 & & & & \\
\hline GOV & $0.32^{*}$ & $0.10^{*}$ & $-0.08^{*}$ & $0.32^{*}$ & $0.33^{*}$ & 1 & & & \\
\hline CRED & $0.53^{*}$ & $0.19^{*}$ & 0.05 & $0.07^{*}$ & $0.17^{*}$ & $0.27^{*}$ & 1 & & \\
\hline HUMAN & $0.66^{*}$ & $0.17^{*}$ & -0.05 & $0.25^{*}$ & $0.46^{*}$ & $0.16^{*}$ & $0.45^{*}$ & 1 & \\
\hline INST & $0.37^{*}$ & $0.17^{*}$ & -0.04 & 0.06 & $0.17^{*}$ & $0.15^{*}$ & $0.28^{*}$ & $0.30^{*}$ & 1 \\
\hline
\end{tabular}

Note: $*$ indicates significance at $5 \%$

The mean for credit to the private sector, a measure of financial development, is $21.94 \%$. High levels of financial development may encourage investments, enhance consumption and improve financial inclusion which in turn promotes human capital and economic development (Levine, 1997, Kuri \& Laha, 2011). According to the data, the most financially developed countries in Africa are South Africa, Mauritius and Tunisia. Human capital is vital for economic development of any nation. A healthy and skilled workforce is more productive and innovative which promotes economic growth (Blanchard, 2017). The continent averages 1.71 with regards to the human capital index. The countries with the highest levels of human capital indices are Botswana, Congo, Egypt, Gabon, Ghana, Mauritius, Namibia, South Africa, Zambia and Zimbabwe. Lastly, the low level of institutional quality has been a major cause for concern for African countries over the years as this discourages investments both domestically and internationally. The selected African countries average 38.44 out of 100 in the level of property rights. The countries with the highest levels of institutional quality are Mauritius and Botswana.

Table 5 shows pairwise correlations between the variables. Manufacturing value added is positively correlated with GDP per capita and significant at the 5\% level, which is in line with a priori expectations. The results also indicate that investments, trade openness, government consumption, human capital and institutional quality are positive and significantly correlated with GDP per capita. Inflation and GDP per capita are negatively correlated as expected, however, the association is insignificant. The correlations between the independent variables are lower than 0.8 , which is an indication of the absence of severe multicollinearity.

\section{Empirical Results}

The empirical results are presented in Table 6. The results of the inferior OLS and Fixed Effects Models are also presented for comparison purposes together with those of the FGLS and System-GMM. The interpretation will be centred on the System-GMM results. Manufacturing value added has a positive impact on GDP per capita and the result is significant at the 1\% level. The result supports Kaldor's hypothesis and indicate that pre-mature deindustrialisation in African countries may hinder economic growth. The results 
confirm those of studies by Libanio and Moro (2006), Mercan et. al. (2015), Olamande and Oni (2016), Cantore et. al. (2017) and Keho (2018), who found support for Kaldor's hypothesis in developing countries. Despite the high levels of economic growth witnessed in Africa over the last few decades, propelled by the commodity price boom, growth has slowed over the last few years which necessitates the need for new policies to reboot economies. The development of the manufacturing sector may be a catalyst for high and sustainable economic growth. The results of the System-GMM model is similar to those of the OLS and FGLS models which also show a positive coefficient for the manufacturing value added.

The result for the FE model indicates a negative coefficient for manufacturing value added, which could be a result of the detected serial correlation and heteroscedasticity. Inflation is negatively signed but insignificant. Despite the high rates of inflation recorded in the past, inflation has not been a major hindrance to economic growth in Africa. Further, most countries have been able to reduce inflation rates to single digit figures over the last decade. Domestic investment has an insignificant effect on output growth in the SystemGMM Model, possibly due to low levels of investment in the region. Trade openness has a positive impact on economic growth in all the models with the exception of the FE model. Trade openness enables countries to specialise in producing goods and services in which they have a comparative advantage, thus resulting in efficient allocation of resources (Salvatore, 2013). Therefore, the region may benefit from initiatives such as the African Free Trade Area signed in 2018.

Government consumption expenditure has an insignificant effect on GDP in the region. This could be the result of the inefficiencies in the public sector in Africa countries. Public expenditure directed at investment activities is more beneficial for economic growth and should be encouraged compared to consumption expenditures. Human capital has a positive and significant influence on economic growth in all models. This reiterates the need for more expenditure towards education and skills development in the region to enhance economic growth. Further, the development of the manufacturing sector is dependent on a highly skilled workforce.

Domestic credit to the private sector is positively related to economic growth and the result is significant at the $1 \%$ level. As mentioned earlier, the development of the financial sector promotes growth through a number of channels. Financial sector development is also vital for the performance of the manufacturing sector by ensuring the availability of funds for investments in physical capital used in production. As expected, institutional quality captured by property rights, has a positive impact on economic growth. The establishment of sound and well-defined property rights are necessary for African countries in order to encourage investments (which includes those in the manufacturing sector) which in turn promotes growth.

Table 6. Regression Results: Dependent Variable: LGDPP

\begin{tabular}{|l|l|l|l|l|l|}
\hline Variable & Pooled OLS & FE & FGLS & GMM & GMM2 \\
\hline MVA & 0.03 & -0.02 & 0.01 & 0.03 & 0.03 \\
& $(8.95)^{* * *}$ & $(-8.62)^{* * *}$ & $(5.09)^{* * *}$ & $(4.18)^{* * *}$ & $(3.17)^{* * *}$ \\
\hline INF & -0.001 & -0.001 & -0.0003 & -0.001 & 0.002 \\
& $(-1.45)$ & $(-3.38)^{* * *}$ & $(-0.10)$ & $(-0.91)$ & $(0.10)$ \\
\hline INV & 0.01 & 0.003 & -0.001 & 0.01 & 0.02 \\
& $(3.46) * * *$ & $(3.67)^{* * *}$ & $(-0.72)$ & $(1.30)$ & $(1.41)$ \\
\hline TRADE & 0.01 & -0.0001 & 0.002 & 0.01 & 0.01 \\
& $(9.08) * * *$ & $(-0.36)$ & $(4.02)^{* * *}$ & $(1.95)^{*}$ & $(2.49)^{* *}$ \\
\hline GOV & 0.01 & -0.01 & 0.002 & 0.004 & -0.01 \\
& $(1.38)$ & $(-3.13)^{* * *}$ & $(1.09)$ & $(0.52)$ & $(-0.30)$ \\
\hline HUMAN & 1.16 & 0.59 & 1.42 & 1.22 & 0.76 \\
& $(14.67) * * *$ & $(15.11) * * *$ & $(28.15)^{* * *}$ & $(6.03)^{* * *}$ & $(2.75)^{* * *}$ \\
\hline CRED & 0.01 & 0.003 & 0.01 & 0.01 & 0.004 \\
\hline
\end{tabular}




\begin{tabular}{|c|c|c|c|c|c|}
\hline & $(9.23) * * *$ & $(4.59) * * *$ & $(7.03)^{* * *}$ & $(4.12)^{* * *}$ & $(0.62)$ \\
\hline INST & $\begin{array}{l}0.003 \\
(1.48)\end{array}$ & $\begin{array}{l}-0.001 \\
(-2.22)^{* *}\end{array}$ & $\begin{array}{l}0.001 \\
(2.63) * * *\end{array}$ & $\begin{array}{l}0.01 \\
(2.12) * *\end{array}$ & $\begin{array}{l}0.01 \\
(4.51)^{* * *}\end{array}$ \\
\hline CONSTANT & $\begin{array}{l}3.50 \\
(25.71) * * *\end{array}$ & $\begin{array}{l}6.34 \\
(75.19) * * *\end{array}$ & $\begin{array}{l}4.19 \\
(45.36)^{* * *}\end{array}$ & $\begin{array}{l}3.60 \\
(13.53) * * *\end{array}$ & $\begin{array}{l}4.01 \\
(10.32)^{* * *}\end{array}$ \\
\hline R-Squared & 0.73 & 0.60 & & & \\
\hline F-statistic & $177.68 * * *$ & $597.29 * * *$ & & $92.71 * * *$ & $73.71 * * *$ \\
\hline $\begin{array}{l}\text { Heteroscedasticit } \\
\mathrm{y}\end{array}$ & & $6475.26 * * *$ & & & \\
\hline Serial correlation & & $56.14 * * *$ & & & \\
\hline A-B AR(2) & & & & {$[0.62]$} & {$[0.80]$} \\
\hline Hansen test & & & & {$[0.73]$} & {$[0.37]$} \\
\hline $\begin{array}{l}\text { Difference-in- } \\
\text { Hansen }\end{array}$ & & & & {$[0.67]$} & {$[0.48]$} \\
\hline
\end{tabular}

Note: Estimations were conducted in Stata 15. Drukker (2003)'s xtserial command is used for testing for serial correlation and the xttest 3 command is used for testing for heteroscedasticity. Roodman (2009)'s xtabond 2 is used for estimating the system-GMM model. *,** and *** indicate significance at $10 \%, 5 \%$ and $1 \%$.

For robustness, checks of the System-GMM model was estimated using data in 5-year averages and the results mirror those above to a large extent. In addition, the System-GMM Models pass all the diagnostic tests and thus can be used for policy analysis.

\section{Conclusion}

The purpose of this study is to test Kaldor's hypothesis on the manufacturing-growth nexus in selected African countries using the System-GMM technique. The Kaldorian laws state that manufacturing is vital for the growth of an economy not only through its direct effect on employment creation, but indirectly by increasing demand in other sectors of the economy such as agriculture, mining and banking. This view is supported by the structuralists who argue that promoting the manufacturing sector is crucial for innovation and gains from productivity.

The decline in MVA in African countries over the last few decades has received considerable attention as the world enters the Fourth Industrial Revolution which has the potential to alter the production of goods and services. Furthermore, unemployment and poverty levels remain high despite decades of positive growth. Due to premature deindustrialisation, African countries may not reap the benefits of high productivity and employment creation that could result from the growth of manufacturing output.

To initiate the analysis, trends in manufacturing and economic growth in African countries was compared to the rest of the world. As shown by the data, the average MVA for the selected African countries is lower than that of other developing/emerging country regions such as South Asia and Latin America and Caribbean countries for the period between 1990 and 2017. The mean value for GDP growth is third behind South Asia and MENA countries, however, this high growth on its own does not indicate prosperity as several countries are still endowed with deep poverty, high inequality and unemployment levels.

The empirical results show that MVA is positively related to economic growth, thus providing support for Kaldor's first law. This result suggests that premature deindustrialisation in African countries hinders economic growth which is detrimental to the region's attempt to reduce unemployment and poverty levels. The empirical model also suggests that trade openness, credit, human capital and institutional quality have a positive and significant impact on economic growth as expected, while inflation, investment and government consumption expenditure have insignificant coefficients. 
This study provides some recommendations for policy makers in SADC countries. Over reliance on primary commodity exports may not be effective in achieving macroeconomic and socio-economic goals of job creation, poverty and inequality reduction. Diversification of the production processes is vital for the sustainability of economic growth and should therefore be implemented. The Fourth Industrial Revolution presents opportunities for African countries to promote innovation and productivity, which are crucial for long-term growth. The manufacturing sector should stimulate productivity and innovation in the whole economy due to its labour-intensive nature. Strengthening of property rights, the development of the financial sector as well as enhancing human capital levels is recommended in order to encourage investments from both foreign and domestic investors, particularly in the manufacturing sector.

\section{References}

Outlook, A. E. (2018). African Development Bank 2012. https://www.afdb.org/fileadmin/uploads/afdb/Documents/Publications/AEO_2017_Report_Full_English.pdf Arellano, M., \& Bover, O. (1995). Another look at the instrumental variable estimation of error-components models. Journal of econometrics, 68(1), 29-51. https://doi.org/10.1016/0304-4076(94)01642-D.

Arellano, M., \& Bond, S. (1991). Some tests of specification for panel data: Monte Carlo evidence and an application to employment equations. The review of economic studies, 58(2), 277-297. https://doi.org/10.2307/2297968

Baltagi, B. H. (2005). Econometric Analysis of Panel Data 3rd Edition England JW \&Sons. https://books.google.com.pk/books?hl=en\&lr=\&id=oQdx_70Xmy0C\&oi=fnd\&pg=PA13\&dq=Baltagi,+B.+H.+(2005).

+ Econometric + Analysis + of + Panel+Data $+3 \mathrm{rd}+$ Edition+England $+\mathrm{JW}+\% 26+$ Sons. \&ots $=\mathrm{xk} 885 \mathrm{z} 5 \mathrm{uSx} \& \mathrm{sig}=8 \mathrm{IZhOY3uO}$ Br81hk2au5HS1wLNzo\#v=onepage \&q\&f=false

Baum, C. F., Schaffer, M. E., \& Stillman, S. (2003). Instrumental variables and GMM: Estimation and testing. The Stata Journal, 3(1), 1-31. https://journals.sagepub.com/doi/abs/10.1177/1536867X0300300101

Bhorat, H., Kanbur, R., Rooney, C., \& Steenkamp, F. (2017). Sub-Saharan Africa's manufacturing sector: Building complexity. https://papers.ssrn.com/sol3/papers.cfm?abstract_id=2980833

Blanchard, O. 2017. Macroeconomics. USA: Pearson.

Blundell, R., \& Bond, S. (1998). Initial conditions and moment restrictions in dynamic panel data models. Journal of econometrics, 87(1), 115-143. https://doi.org/10.1016/S0304-4076(98)00009-8.

Brooks, C. (2008). Introductory Econometrics for Finance, 2008.

Cantore, N., Clara, M., Lavopa, A., \& Soare, C. (2017). Manufacturing as an engine of growth: Which is the best fuel?. Structural Change and Economic Dynamics, 42, 56-66.http://dx.doi.org/10.1016/j.strueco.2017.04.004.

Chakravarty, S., \& Mitra, A. (2009). Is industry still the engine of growth? An econometric study of the organized sector employment in India. Journal of Policy Modeling, 31(1), 22-35. https://doi.org/10.1016/j.jpolmod.2008.06.002

Chenery, H. B. (1975). The structuralist approach to development policy. The American Economic Review, 65(2), 310316. https://www.jstor.org/stable/1818870

Drukker, D. M. (2003). Testing for serial correlation in linear panel-data models. The stata journal, 3(2), 168-177. https://doi.org/10.1177/1536867X0300300206

Lederman, D., Lesniak, J. T., Feenstra, R. C., Inklaar, R., \& Timmer, M. P. (2017). "The Next Generation of the Penn World Table. https://doi.org/10.1596/978-1-4648-1042-8_bm

Greene, W. H. (2003). Econometric analysis. Pearson Education India. https://books.google.com.pk/books?hl=en\&lr=\&id=njAcXDIR5U8C\&oi=fnd\&pg=PR1\&dq=Greene,+W.+H.+2002.+E conometric+Analysis.+New+York:+Pearson+Education.\&ots=pYtGwPTEmL\&sig=jRRo82BrqqOCTEHg0fNvAWxd HUU\&redir_esc=y\#v=onepage \&q=Greene $\% 2 C \% 20 \mathrm{~W} . \% 20 \mathrm{H} . \% 202002 . \% 20 \mathrm{Econometric} \% 20$ Analysis. $\% 20 \mathrm{New} \% 20 \mathrm{Y}$ ork $\% 3 \mathrm{~A} \% 20$ Pearson\%20Education.\&f=false

Gujarati, D. N. (2009). Basic econometrics. Tata McGraw-Hill Education. https://books.google.com.pk/books?hl=en\&lr=\&id=WcCjAgAAQBAJ\&oi=fnd\&pg=PR3\&dq=Gujarati,+D.N.+\%26+P orter,+D.C.+2009.+Basic+Econometrics.+5th+Edition.+Singapore:+McGraw-

Hill.\&ots=eakv11RcQN\&sig=ypXdkVJ69mlGQCoB_PrcuMW_h64\&redir_esc=y\#v=onepage\&q\&f=false 
Haraguchi, N., Cheng, C. F. C., \& Smeets, E. (2017). The Importance of manufacturing in Economic Development: Has this changed?. World Development, 93, 293-315. https://doi.org/10.1016/j.worlddev.2016.12.013

Heritage Foundation (Washington, \& Wall Street Journal (Firm). (2009). The index of economic freedom. Heritage Foundation.https://www.heritage.org/index/download.

Hill, R. C., Griffiths, W. E., \& Lim, G. C. (2012). Principles of Econometrics Fourth Edition. New Jersey: Hoboken.

Hsiao, C. (2007). Panel data analysis-advantages and challenges. Test, 16(1), 1-22. https://link.springer.com/article/10.1007/s11749-007-0046-X

Jeon, Y. (2006). Manufacturing, increasing returns and economic development in China, 1979-2004: a Kaldorian approach. University of Utah Department of Economics Working Paper Series, 8. https://economics.utah.edu/research/publications/2006_08.pdf

Kaldor, N. (2007). Causes of growth and stagnation in the world economy. Cambridge University Press. https://books.google.com.pk/books?hl=en\&lr=\&id=c3xSSuVDrB0C\&oi=fnd\&pg=PP1\&dq=Kaldor,+N.,+1960.+Cause s+of+Growth+and+Stagnation+in+the+World+Economy.+Cambridge:+Cambridge+University+Press.\&ots=gJSejrT5d a\&sig=q4me-

C3QvRMFRc7X5JrgpCgwGQE\&redir_esc=y\#v=onepage\&q=Kaldor\%2C\%20N.\%2C\%201960.\%20Causes\%20of\%20 Growth\%20and\%20Stagnation\%20in\%20the\%20World\%20Economy.\%20Cambridge\%3A\%20Cambridge\%20Univers ity $\% 20$ Press.\&f=false

Keho, Y. (2018). Manufacturing and Economic Growth in ECOWAS Countries: A Test of Kaldor's First Law. Modern Economy, 9(5). https://doi.org/10.4236/me.2018.95057.

Kuri, P. K., \& Laha, A. (2011). Financial inclusion and human development in India: an inter-state analysis. Indian Journal of Human Development, 5(1), 61-77.https://doi.org/10.1177/0973703020110103.

Levine, R. (1997). Financial development and economic growth: points of view and agenda. The Economic Journal, 35 (2), 688-726. https://www.jstor.org/stable/2729790

Libanio, G., \& Moro, S. (2006, December). Manufacturing industry and economic growth in Latin America: A Kaldorian approach. In Second Annual Conference for Development and Change. http://www.networkideas.org/ideasact/jun07/Beijing_Workshop_07/Gilberto_Libanio.pdf

Mercan, M., Kizilkaya, O. \& Okde, B. 2015. Are Kaldor's laws valid? Panel data analysis under cross-section dependency for NIC countries. Procedia Economics and Finance, 23: 140-145. doi: 10.1016/S2212-5671(15)00399-8.

Marconi, N., de Borja Reis, C. F., \& de Araújo, E. C. (2016). Manufacturing and economic development: The actuality of Kaldor's first and second laws. Structural Change and Economic Dynamics, 37, 75-89. http://dx.doi.org/10.1016/j.strueco.2015.12.002.

Morris, M., \& Fessehaie, J. (2014). The industrialisation challenge for Africa: Towards a commodities based industrialisation path. Journal of African Trade, 1(1), 25-36. https://doi.org/10.1016/j.joat.2014.10.001

Moyo, C., \& Le Roux, P. (2018). Interest rate reforms and economic growth: the savings and investment channel. https://mpra.ub.uni-muenchen.de/85297/

Olamade, O., \& Oni, O. (2016). Manufacturing and economic growth in Africa: A panel test of kaldor's first growth law. Journal of Economics and Sustainable Development, 7(22), $126-140$. https://www.researchgate.net/profile/Olumuyiwa_Olamade2/publication/312044644_Manufacturing_and_Economic_G rowth_in_Africa_A_Panel_Test_of_Kaldor\%27s_First_Growth_Law/links/586cb6d208ae8fce4919f205/Manufacturing -and-Economic-Growth-in-Africa-A-Panel-Test-of-Kaldors-First-Growth-Law.pdf

Rasiah, R. (1996). Manufacturing as engine of growth and industrialisation in Malaysia. Managerial Finance, 22(5), 87117. https://doi.org/10.1108/eb018566

Rocha I. L. 2018. Manufacturing as driver of economic growth. PSL Quarterly Review, 71(285): 1-36. http://dx.doi.org/10.13133/2037-3643_71.285_2

Rodrik, D. (2016). Premature deindustrialization. Journal of Economic Growth, 21(1), 1-33.doi: 10.1007/s10887-0159122-3.

Romer, D. (2012). Dynamic Stochastic General Equilibrium Models of Fluctuations. Advanced Macroeconomics. Fourth ed. New York: McGraw-Hill $\quad 312-364$. https://www.academia.edu/36019638/Advanced_Macroeconomics_4th_Edition_by_David_Romer

Roodman, D. (2009). How to do xtabond2: An introduction to difference and system GMM in Stata. The stata journal, 9(1), 86-136. https://ideas.repec.org/a/tsj/stataj/v9y2009i1p86-136.html 
Salvatore, D. (2013). International Economics (11. bask1).

Singaariya, M. R., \& Sinha, N. (2015). Relationships among per capita GDP, agriculture and manufacturing sectors in India. Journal of Finance and Economics, 3(2), 36-43.doi:10.12691/jfe-3-2-2.

$\mathrm{Su}, \mathrm{D} .$, \& Yao, Y. (2017). Manufacturing as the key engine of economic growth for middle-income economies. Journal of the Asia Pacific Economy, 22(1), 47-70. https://doi.org/10.1080/13547860.2016.1261481

Szirmai, A., \& Verspagen, B. (2010, August). Is Manufacturing Still an Engine of Growth in Developing Countries?. In 31st General Conference of The International Association for Research in Income and Wealth (pp. 22-28). DOI: 10.1016/j.strueco.2015.06.002

Szirmai, A. (2012). Industrialisation as an engine of growth in developing countries, 1950-2005. Structural change and economic dynamics, 23(4), 406-420. https://doi.org/10.1016/j.strueco.2011.01.005.

Tsoku, J. T., Mosikari, T. J., Xaba, D., \& Modise, T. (2017). An Analysis of the Relationship between Manufacturing Growth and Economic Growth in South Africa: A Cointegration Approach. World Academy of Science, Engineering and Technology, International Journal of Social, Behavioral, Educational, Economic, Business and Industrial Engineering, $11(2)$

414-419. https://www.researchgate.net/profile/Johannes_Tsoku/publication/314086190_An_Analysis_of_the_Relationship_betw een_Manufacturing_Growth_and_Economic_Growth_in_South_Africa_A_Cointegration_Approach/links/595a5fe0458 515a5406fc9b4/An-Analysis-of-the-Relationship-between-Manufacturing-Growth-and-Economic-Growth-in-SouthAfrica-A-Cointegration-Approach.pdf

Udedechinyere, C., Michael, O. \& Mbam, N.A. 2018. An analysis of the effect of manufacturing sector on the growth of the Nigerian economy. Journal of Business and Management, 20(4): 34-46. Retrieved from www.iosrjournals.org.

Rahman, M. Z., Waly, H., \& Msadek, S. (1999). World development indicators 1999. The World Bank. http://agris.fao.org/agris-search/search.do?recordID=US2012424268

Schwab, K. (2013). The Human Capital Report 2013. In Geneva: World Economic Forum. http://reports.weforum.org/human-capital-report-2016/technical-notes/

Zeileis, A. (2017). pwt9: Penn World Table (Version 9. x). R package version, 9-0. https://rdrr.io/cran/pwt9/

\section{Appendix}

List of countries

\begin{tabular}{|l|l|l|l|l|}
\hline $\begin{array}{l}\text { SADC/Southern } \\
\text { Africa }\end{array}$ & Central Africa & West Africa & East Africa & North Africa \\
\hline Angola & $\begin{array}{l}\text { Central African } \\
\text { Republic }\end{array}$ & Benin & & \\
\hline Botswana & Congo & Burkina Faso & Burundi & Algeria \\
\hline DRC & & Cameroun & Kenya & Egypt \\
\hline Eswatini & & Gabon & Rwanda & Morocco \\
\hline Lesotho & & The Gambia & Sudan & Tunisia \\
\hline Madagascar & & Ghana & Uganda & \\
\hline Malawi & & Ivory Coast & & \\
\hline Mauritius & Liberia & & \\
\hline Namibia & Mauritania & & \\
\hline South Africa & & Niger & & \\
\hline Tanzania & Nigeria & & \\
\hline Zambia & & Sierra Leone & & \\
\hline Zimbabwe & Togo & & \\
\hline
\end{tabular}

